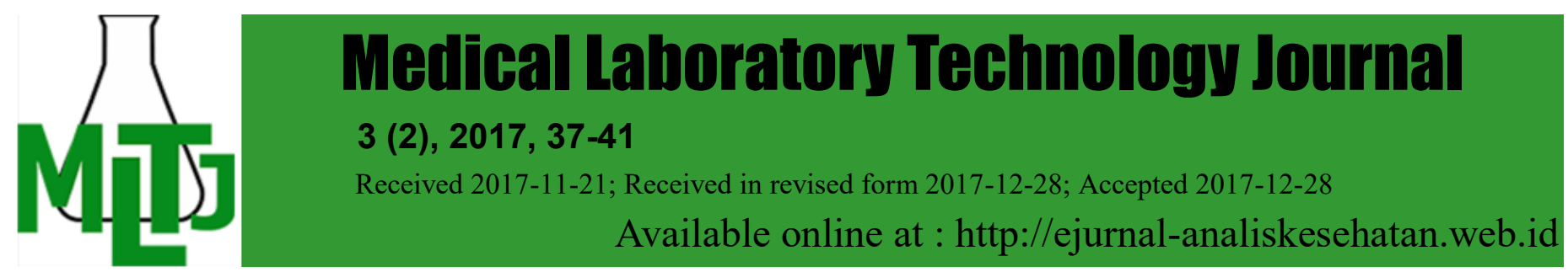

\title{
AKURASI HITUNG JUMLAH ERITROSIT METODE MANUAL DAN METODE OTOMATIS
}

\author{
Neni Oktiyani, Fahriyan, Ahmad Muhlisin \\ Jurusan Analis Kesehatan Poltekkes Kemenkes Banjarmasin \\ JI Mistar Cokrokusumo 4a Banjarbaru \\ e-mail: nine.ok76@gmail.com
}

\begin{abstract}
In a laboratory, an erythrocyte is done by using hemocytometer and microscope. The task is to measure and assess the size and shape of the erythrocyte. But this procedure is time consuming, complex and tedious. As a solution to this problem, to provide an automated, cost-effective and efficient alternative to detection and counting of erythrocyte, hematology analyzers are used. However, false results related either to erythrocyte or other parameters from complete blood count may be observed in several instances. The objective study was to compare the accuracy of erythrocyte count results of automatic hematological analysis by the manual method. The study is an analytic survey with a cross-sectional design. Erythrocyte counting is done by using three types of control blood, namely high, normal and low, with 9 repetitions. In high control blood, the mean erythrocytes count by the manual method was $7.08 \mathrm{million} / \mu \mathrm{l}$ with a bias value of $1.4 \%$, while that by the automated method was $7.03 \mathrm{million} / \mu \mathrm{l}$ with a bias value of $0.7 \%$. The mean erythrocyte count in normal control blood by the manual method was $4.50 \mathrm{million} / \mu \mathrm{l}$ with a bias value of $0.9 \%$, while that by the automated method was $4.4 \mathrm{million} / \mu \mathrm{l}$ with a bias value of $2.4 \%$. And in low control blood, the mean erythrocyte count by the manual method was 1.72 million/ $\mu$ l with $4.4 \%$ bias value, while that the automated method was 1.67 million/ $\mu$ l with $1.2 \%$ bias value. Statistical analysis showed no significant difference in accuracy between the erythrocyte count of manual methods with automated methods.
\end{abstract}

Keywords: erythrocytes counting; manual method; automated method

Abstrak: Hitung jumlah eritrosit dilakukan dengan menggunakan metode manual dan metode otomatis. Metode manual menggunakan alat Hemositometer dapat memberikan hasil yang dipercaya dan akurat tergantung keahlian dari teknisi laboratorium. Metode otomatis memberikan hasil yang lebih mudah, cepat dan teliti dibandingkan dengan cara manual. Tujuan penelitian untuk membandingkan akurasi hitung jumlah eritrosit metode manual dan metode otomatis. Jenis penelitian yang digunakan adalah survey analitik dengan rancangan cross sectional. Penelitian ini membandingkan data hasil hitung jumlah eritrosit antara metode manual dengan metode otomatis dengan menggunakan 3 jenis darah kontrol hitung jumlah eritrosit high, normal, dan low dengan 9 kali pengulangan. Hasil penelitian menunjukkan nilai rerata hitung jumlah eritrosit darah kontrol high metode manual sebesar 7,08 juta/ $\mu$ l dengan nilai bias $1,4 \%$ dan metode otomatis sebesar 7,03 juta/ $\mu$ l dengan nilai bias $0,7 \%$. Rerata hitung jumlah eritrosit darah kontrol normal metode manual sebesar 4,50 juta/ $\mu$ l dengan nilai bias 0,9\% dan metode otomatis sebesar 4,43 juta/ $\mu$ l dengan nilai bias $2,4 \%$. Rerata hitung jumlah eritrosit darah kontrol low metode manual sebesar 1,72 juta/ul dengan nilai bias $4,4 \%$ dan metode otomatis sebesar 1,67 juta/ $\mu$ l dengan nilai bias 1,2\%. Uji statistik menunjukkan tidak ada perbedaan akurasi yang bermakna antara hitung jumlah eritrosit metode manual dengan metode otomatis.

Kata kunci: hitung jumlah eritrosit; manual; otomatis 


\section{PENDAHULUAN}

Sel darah merah atau eritrosit merupakan sel darah dengan jumlah yang paling banyak dalam tubuh manusia. Fungsi utama eritrosit adalah mengangkut oksigen dan mengantarkannya ke sel-sel tubuh. Hitung jumlah eritrosit merupakan salah satu parameter Hematologi yang ditentukan guna membantu menegakkan diagnosis, menunjang diagnosis, membuat diagnosis banding, memantau perjalanan penyakit, menilai beratnya sakit dan menentukan prognosis (Wirawan, 2011).

Pemeriksaan hitung jumlah eritrosit secara manual dengan alat Hemositometer merupakan metode yang paling umum digunakan karena lebih murah (Herrera, 2015). Metode ini biasanya digunakan pada rumah sakit dan laboratorium klinik berskala kecil dengan beban kerja yang tidak terlalu besar (Ranjan, 2016). Pada metode ini, eritrosit dihitung dengan bantuan mikroskop. Namun hitung jumlah eritrosit dengan metode ini membutuhkan waktu yang cukup lama dan rumit. Selain itu akurasi hasil pemeriksaan dipengaruhi oleh faktor subyektif seperti pengalaman dan keahlian dari teknisi laboratorium, dan faktor kelelahan dari teknisi terutama jika sampel pemeriksaan dalam jumlah yang sangat besar. Metode otomatis digunakan sebagai solusi masalah tersebut karena lebih efektif dan efisien (Pandit, 2015).

Pada metode otomatis, pengukuran hitung jumlah eritrosit (red blood cell/RBC) menggunakan prinsip impedansi. Sel dihitung dan diukur berdasarkan pada pengukuran perubahan hambatan listrik yang dihasilkan oleh sebuah partikel, dalam hal ini adalah sel darah yang disuspensikan dalam pengencer konduktif saat melewati celah dimensi. Sel-sel darah yang melewati celah dengan elektroda di kedua sisinya mengalami perubahan impedansi yang menghasilkan getaran listrik yang terukur sesuai dengan volume atau ukuran sel. Amplitude setiap getaran sebanding dengan volume setiap partikel. Setiap getaran diperkuat dan dibandingkan dengan saluran tegangan acuan internal, yang hanya menerima getaran dari amplitude tertentu. Jika getaran range $R B C$, maka dihitung sebagai $R B C$. Prinsip pengukuran jumlah sel ini tergantung pada ukuran sel, luas permukaan, dan adanya granula-granula di dalam sel (Mindray BC3200 Operator's Manual, 2012; Kakel, 2013).
Hasil hitung jumlah eritrosit yang rendah palsu dapat diakibatkan karena adanya pengkerutan sel eritrosit yang dapat terbaca sebagai trombosit pada alat Hematology Analyzer (Mindray BC-3200 Operator's Manual, 2012). Pada kondisi ini, metode manual dapat dilakukan sebagai uji konfirmasi hitung jumlah eritrosit. Penelitian adanya korelasi antara metode manual dan metode otomatis terhadap hitung jumlah eritrosit masih jarang dan sering menjadi perdebatan (Ike, 2010). Oleh karena itu penelitian ini bertujuan untuk mengetahui perbandingan akurasi hitung jumlah eritrosit metode manual dengan metode otomatis.

\section{BAHAN DAN METODE}

Jenis penelitian ini adalah study comparative membandingkan antar dua kelompok data dengan rancangan Cross Sectional. Pada penelitian ini membandingkan data hasil hitung jumlah eritrosit antara metode manual dengan data hasil hitung jumlah eritrosit metode otomatis dengan menggunakan darah kontrol hitung jumlah eritrosit.

Penelitian dilakukan menggunakan 3 jenis darah kontrol high, normal, dan low dengan 9 kali pengulangan untuk masing-masing metode. Pemeriksaan hitung jumlah eritrosit manual dilakukan menggunakan alat Hemositometer dan metode otomatis menggunakan Mindray BC-3200 Auto Hematology Analyzer.

Data yang diperoleh kemudian dihitung nilai rerata dan nilai akurasinya dengan \% nilai bias. Nilai bias dihitung dari selisih nilai rerata hasil hitung jumlah eritrosit dengan nilai rerata darah kontrol dibagi nilai rerata darah kontrol kemudian dikali seratus persen. Uji statistik Independent Samples $T$ Test dilakukan menggunakan perangkat komputer dengan nilai signifikansi $a=0,05$.

\section{HASIL DAN PEMBAHASAN Hasil Hitung Jumlah Eritrosit}

Hitung jumlah eritrosit pada penelitian ini dilakukan pada 3 jenis darah kontrol high

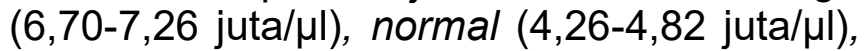

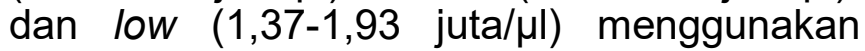
metode manual dan metode otomatis. Pemeriksaan hitung eritrosit pada tiap jenis darah kontrol dengan metode manual dan otomatis dilakukan sebanyak 9 kali pengulangan. Data hasil hitung jumlah eritrosit dapat dilihat pada Tabel 1. 
Tabel 1 Data hasil hitung jumlah eritrosit (juta/ $\mu \mathrm{l}$ ) metode manual dan otomatis

\begin{tabular}{ccc}
\hline Darah Kontrol & Metode Manual & Metode Otomatis \\
\hline High & 7,00 & 6,74 \\
High & 7,30 & 7,06 \\
High & 7,20 & 7,07 \\
High & 7,00 & 7,11 \\
High & 6,80 & 6,97 \\
High & 7,10 & 7,06 \\
High & 7,20 & 7,17 \\
High & 7,30 & 6,92 \\
High & 6,80 & 7,19 \\
Normal & 4,60 & 4,35 \\
Normal & 4,50 & 4,38 \\
Normal & 4,40 & 4,43 \\
Normal & 4,30 & 4,46 \\
Normal & 4,50 & 4,46 \\
Normal & 4,50 & 4,47 \\
Normal & 4,60 & 4,48 \\
Normal & 4,40 & 4,44 \\
Normal & 4,60 & 4,42 \\
Low & 1,80 & 1,73 \\
Low & 1,70 & 1,70 \\
Low & 1,70 & 1,66 \\
Low & 1,80 & 1,64 \\
Low & 1,80 & 1,65 \\
Low & 1,80 & 1,66 \\
Low & 1,60 & 1,66 \\
Low & 1,60 & 1,71 \\
Low & 1,70 & 1,69 \\
\hline & &
\end{tabular}

Berdasarkan data pada Tabel 1 dapat dilihat bahwa terdapat 2 (dua) nilai hitung jumlah eritrosit pada metode manual dengan darah kontrol high yang keluar dari range darah kontrol $(6,70-7,26$ juta/ $/$ l) yaitu sebesar 7,30

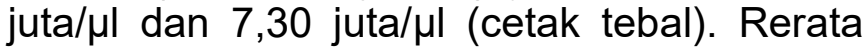
hasil hitung jumlah eritrosit metode manual dan otomatis masih dalam range darah kontrol, baik darah control high, normal, maupum low (Gambar 1).

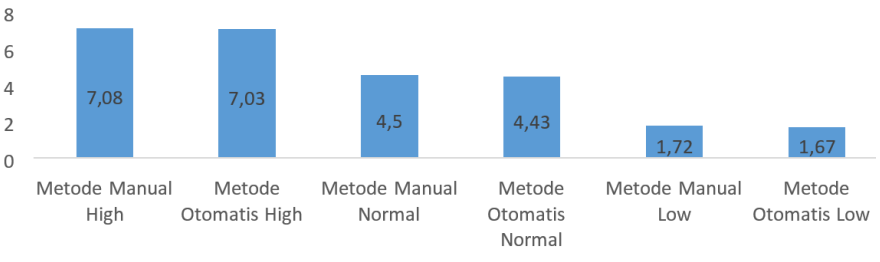

Gambar 1. Grafik Rerata Hitung Jumlah Eritrosit

\section{Nilai Akurasi}

Nilai akurasi dihitung menggunakan nilai persentase bias, hasil analisis dikatakan semakin akurat jika diperoleh nilai bias paling rendah $(0 \%)$.

Rumus menentukan nilai \% Bias:

$$
\frac{A-B}{B} \times 100 \%=\% \text { Bias }
$$

Keterangan:

A: Rerata hasil hitung jumlah eritrositt

B: Rerata nilai darah kontrol

Tabel 2. Nilai bias hitung jumlah eritrosit metode manual dan otomatis

\begin{tabular}{crcr}
\hline Metode & \multicolumn{3}{c}{ Nilai bias } \\
\cline { 2 - 4 } & High & Normal & Low \\
\cline { 2 - 4 } Manual & $1,4 \%$ & $0,9 \%$ & $4,4 \%$ \\
Otomatis & $0,7 \%$ & $2,4 \%$ & $1,2 \%$ \\
\hline
\end{tabular}

Tabel 2 menunjukkan bahwa nilai bias terendah pada metode manual yaitu dengan darah kontrol normal sebesar $0,9 \%$ dan pada metode otomatis dengan darah kontrol High sebesar $0,7 \%$.

\section{Uji Statistik}

Perbandingan akurasi hasil hitung jumlah eritrosit metode manual dengan metode otomatis untuk masing-masing darah kontrol high, normal dan low dilakukan menggunakan Independent Samples T Test. Hasil uji hitung jumlah eritrosit menggunakan metode manual dan otomatis dengan darah kontrol high, normal dan low diperoleh nilai signifikansi berturut-turut sebesar 0,573, 0,165 , dan 0,164 . Hal ini menunjukkan bahwa nilai signifikasi $>0,05$ yang berarti tidak ada perbedaan akurasi antara hitung jumlah eritrosit metode manual dengan metode otomatis untuk semua darah kontrol.

Hasil hitung jumlah eritrosit pada metode manual dan otomatis, terdapat 2 (dua) nilai hitung jumlah eritrosit pada metode manual dengan darah kontrol high yang keluar dari range darah kontrol $(6,70-$ $7,26 \mathrm{juta} / \mu \mathrm{l})$ yaitu sebesar $7,30 \mathrm{juta} / \mu \mathrm{l}$ dan 7,30 juta/ $\mu$ l. Namun rerata hasil hitung jumlah eritrosit metode manual dan otomatis untuk semua darah kontrol high, normal, dan low masih dalam range darah kontrol. Kesalahan yang sering terjadi pada metode manual terutama akibat pengambilan sampel, pengenceran dan pemipetan yang kurang tepat. Kesalahan pada penghitungan jumlah sel eritrosit ini adalah 15-30\% (Math, 2016). 
Pengambilan sampel, pengenceran dan pemipetan yang kurang tepat dapat menyebabkan darah dan larutan pengencer tidak homogen sehingga hitung jumlah eritrosit tidak menjadi representatif dan hasil yang didapatkan tidak akurat. Kesalahan lain yang dapat terjadi adalah berkaitan dengan kamar hitung dan teknik menghitung sel eritrosit. Hitung jumlah sel harus sesuai dengan aturan agar eritrosit tidak terhitung berulang (Kiswari, 2014). Pada metode manual, ketelitian hasil hitung jumlah eritrosit sangat tergantung pada keahlian dan pengalaman dari teknisi laboratorium (Pandit, 2015; Ranjan, 2016).

Akurasi hasil hitung jumlah eritrosit metode manual dan otomatis dihitung berdasarkan nilai bias, dimana dikatakan akurat jika nilai bias $0 \%$. Hasil hitung jumlah eritrosit dengan menggunakan darah kontrol high pada metode manual diperoleh nilai bias sebesar $1,4 \%$ dan metode otomatis sebesar $0,7 \%$. Pada hitung jumlah eritrosit metode manual dengan menggunakan darah kontrol normal didapatkan nilai bias sebesar $0,9 \%$ dan metode otomatis sebesar 2,4\%. Untuk darah kontrol low, akurasi hitung jumlah eritrosit metode manual diperoleh nilai bias sebesar $4,4 \%$ dan metode otomatis sebesar $1,2 \%$. Hitung jumlah eritrosit menggunakan metode manual memiliki nilai akurasi lebih baik daripada metode otomatis pada darah kontrol normal, sedangkan hitung jumlah eritrosit menggunakan metode otomatis nilai akurasi lebih baik daripada metode manual pada darah kontrol high dan low. Namun hasil dari uji statistik menggunakan Independent Samples $T$ Test diperoleh nilai signifikansi $>0,05$ pada kedua metode untuk semua darah kontrol. Hal ini berarti tidak terdapat perbedaan bermakna antara hasil hitung jumlah eritrosit metode manual dengan metode otomatis dengan menggunakan darah kontrol high, normal dan low.

Pada penelitian sebelumnya yang dilakukan Thabit (2006), menunjukkan bahwa tidak terdapat perbedaan bermakna hasil pemeriksaan hematokrit antara penggunaan metode mikrokapiler dengan metode Hematology Analyzer. Demikian pula penelitian yang dilakukan oleh Maulidha (2006) tentang perbandingan hitung jumlah trombosit metode Rees-ecker dengan Hematology Analyzer menunjukkan bahwa tidak ada perbedaan yang bermakna dari hasil hitung jumlah trom- bosit kedua metode tersebut. Penelitian yang dilakukan Wahid (2015) terhadap hitung jenis leukosit diperoleh hasil tidak ada perbedaan bermakna antara nilai hitung jenis leukosit eosinophil, netrofil, limfosit dan monosit menggunakan metode manual dengan metode otomatis. Babadoko (2016) melakukan penelitian terhadap pasien normal menunjukkan bahwa nilai rerata hitung hematokrit dan hitung jumlah leukosit menggunakan metode manual tidak berbeda bermakna dengan metode otomatis, namun terdapat perbedaan yang bermakna pada hitung jumlah trombosit. Penelitian serupa yang dilakukan Bakhubaira (2013) juga menunjukkan tidak ada perbedaan bermakna antara hitung jumlah trombosit metode manual dengan metode otomatis pada darah pasien low dan normal, tetapi berbeda bermakna pada darah pasien high.

Metode otomatis menggunakan Hematology Analyzer dapat digunakan untuk pemeriksaan rutin hitung jumah eritrosit dengan tujuan agar memperoleh hasil yang cepat dan akurat. Namun metode ini dapat memberikan hasil palsu pada keadaan sel yang abnormal. Hasil yang abnormal pada hitung jumlah eritrosit dapat disebabkan oleh adanya cryoglobulins, lipid, aglutinin dan adanya peningkatan jumlah sel leukosit (Zandecki, 2007). Kesalahan perbandingan antara antikoagulan dengan volume darah dapat menyebabkan perubahan ukuran eritrosit. Konsentrasi EDTA yang tinggi menyebabkan eritrosit menyusut karena hipertonisitas plasma (Patel, 2009). Sehingga metode manual digunakan sebagai tes konfirmasi jika perhitungan jumlah eritrosit pada alat otomatis memberikan hasil yang meragukan.

\section{KESIMPULAN}

Tidak ada perbedaan bermakna nilai akurasi hasil hitung jumlah eritrosit antara metode manual dengan metode otomatis menggunakan darah kontrol high, normal, dan low. Hitung jumlah eritrosit di laboratorium klinik dapat menggunakan metode otomatis untuk mendapatkan hasil yang cepat dan akurat, namun tetap disertai metode manual sebagai uji konfirmasi dalam memberikan informasi diagnosa. 


\section{SARAN}

Untuk peneliti selanjutnya dapat dilakukan penelitian perbandingan hasil pemeriksaan hitung jumlah eritrosit menggunakan metode hapusan darah dan metode otomatis.

\section{DAFTAR PUSTAKA}

Babadoko AA, Ibrahim IN, Musa U, \& Usman N. (2016). Reproducibility of Hematological Parameters: Manual Versus Automated Method. Sub-Saharan African Journal of Medicine, 3(2), 65-70.

Bakhubaira S. (2013). Automated Versus Manual Platelet Count in Aden. J Clin Exp Pathol, 3(149).

Herrera DC, DeLara- Esparza JE, Ramírezlbañez ND, Carlos A. Morales L, Pérez NO, Flores-Ortiz LF, \& Medina-Rivero E. (2015). Validation of three viable-cell counting methods:Manual, semiautomated, and automated. Elsevier: Biotechnology Reports, 7, 9-16.

Ike SO, Nubila T, Ukaejiofo EO, Nubila IN, Shu EN, \& Ezema I. (2010). Comparison of haematological parameters determined by the Sysmex KX-2IN automated haematology analyzer and the manual counts. BMC Clin Pathol, 10(3).

Kakel SJ. (2013). The evaluation of traditional and automatic Coulter method in estimation haematological parameters in adult rats. Beni-Suef University Journal of Basic and Applied Sciences, 2(1), 31 $-35$.

Kiswari R. (2014). Hematologi dan Transfusi. Jakarta: Erlangga.

Math MV, Kattimani YR, Khadkikar RM, Patel SM, Shanti V, \& Inandar RS. (2016). Red Blood Cell Count: Brief History and New Method. MGM J Med Sci, 3(3), 116-119.

Maulidha SR. (2006). Perbandingan Jumlah Trombosit Metode Reesecker Dengan Hematology Analyzer. Poltekkes Kemenkes Banjarmasin Jurusan Analis Kesehatan.

Mindray. (2012). BC-3200 Auto Hematology Analyzer Operator's Manual. Shenzhen Mindray Bio-medical Electronics Co., Ltd.

Pandit A, Kolhar S, \& Patil P. (2015). Survey on Automatic RBC Detection and Counting. International Journal of Ad- vanced Research in Electrical, Electronics and Instrumentation Engineering, 4 (1), 128-131.

Patel N. (2009). Why is EDTA The Antocoagulant of choice for Hematology Use? Tech Talk, 7(1).

Ranjan R, Singh RK, \& Rigvardhan. (2016). Cost effectiveness \& accuracy analysis of mannual versus automated methods of estimation of basic haematological parameters in a resource poor setting. Indian Journal of Basic and Applied Medical Research, 5(4), 121-127.

Thabit MR. (2006). Perbandingan Nilai Hematokrit Pada Penggunaan Metode Mikrohematokrit Dan Metode Hematology Analyzer Bulan April 2006. Poltekkes Kemenkes Banjarmasin Jurusan Analis Kesehatan.

Wahid AA, \& Purwaganda W. (2015). Perbandingan Hasil Pemeriksaan Hitung Jenis Leukosit Menggunakan Metode Manual dengan Laser-Based Flowcytometry. Jurnal Kesehatan Rajawali, 5 (9), 24-27.

Wirawan, R. (2011). Pemeriksaan Laboratorium Hematologi. Jakarta: Badan Penerbit FKUI.

Zandecki M, Genevieve F, Gerald J, \& Gordon A. (2007). Spurious counts and spurious results on hematology analysers. International Journal of Laboratory Hematology, 29(1), 21-41. 